\title{
Road Edge Parking Management Strategy in Semarang City: Collaborative Governance Perspective
}

\author{
Maya Rumantir ${ }^{1}$, Hardi Warsono ${ }^{2}$, Budi Puspo Priyadi ${ }^{3}$, Retno Sunu Astuti ${ }^{4}$, Teuku \\ Afrizal $^{5 *}$ \\ 1,2,3,4,5 Public Administration, Faculty of Social and Political Sciences, Universitas Diponegoro Semarang, \\ Indonesia \\ maya_rumantir@yahoo.com,teukurian@lecturer.undip.ac.id*
}

\begin{abstract}
Roadside parking makes a large contribution to local revenue if managed properly. However, in its implementation, there have been many practices of "illegal parking" which have made the management very bad and caused losses to the parking users. Thus, government collaboration in parking management is important to involve all relevant stakeholders involved as a whole, forming cooperation, both in consensus and in decision making. This study focuses on-street parking management strategy from a collaborative governance perspective. This study used a descriptive qualitative method with the research location in the city of Semarang. Data collection was carried out through in-depth interviews with related agencies, apart from observing and documenting. From observations in the field, the researchers found that the Semarang City Government has not performed its function optimally as the main pillar in determining policies related to parking management. For this reason, a management strategy with a government collaboration concept approach that involves several stakeholders is needed to solve the parking problem collectively. With the concept of collaborative governance, it will reduce irregularities and monopolies in the implementation of parking management.
\end{abstract}

Keywords

collaborative governance; parking management; on street-parking, parking policy

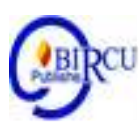

\section{Introduction}

The parking phenomenon occurs in major cities throughout Indonesia. Parking can be in the form of parking for motorized vehicles or non-motorized vehicles. Parking is an absolute facility needed by vehicle owners who want to park their vehicles in easy-to-reach places, one of which is on the edge of a public road. Parking management is a problem that has caught the attention of the public, ranging from high parking rates, illegal parking to disagreements about which location regulations are allowed or not to be parked.

Unsuitable parking is a problem because it is one of the factors that cause congestion, disturbs road users, and even becomes one of the factors that reduce the beauty of the city. The absence of parking facilities (special spaces or parking buildings) in certain areas in the city has made roads become an alternative parking space. This refers to the activity of on-street parking which is considered to provide a very large revenue contribution to the government and become a magnet for certain parties as well as the factors causing the practice of illegal parking.

In the city of Semarang, the parking issue is still a problem so that it is difficult to find a solution. According to Hendrawan Tomi Taruno (2017), parking management in Semarang City is still very bad. This is proven by the large number of parking service users who complain about the poor service and there are still many people who practice illegal parking at rates that do not comply with the policy provisions set by the Semarang 
City Government. Mismanagement and systems lead to potential revenue leaks. Hendrawan added that there are indications that the practice of illegal parking is supported by the rulling class and "playing" in the management of illegal parking.

Given the current condition of parking problems in the city of Semarang, an effective parking management strategy is very important. Proper management planning will affect traffic flow, order and reduce potential losses for both the Semarang City Government and parking service users. This of course will also contribute to the sustainability of transportation development in the city of Semarang. In essence, parking management is part of the Regional Government's public policy which has the authority to regulate which places are allowed and cannot so that people, like it or not, are obliged to comply. Looking at some of the problems that exist, There is a need for an assessment of several actors who have authority in management of estimates in Semarang City from the perspective of collaborative governance. Collaborative governance is a governance process in policy making and implementation by involving stakeholders, both public and private, to collaborate collectively in the process of decision making and policy implementation based on agreement or consensus.

In the perspective of government collaboration in governance, the Semarang City Government no longer carries out a single policy but also involves the private sector working collectively to enact laws and regulations. There are several sectors or related institutions that have the authority to manage parking in the city of Semarang, namely; Semarang City Transportation Agency (Dishub), Praja Police Unit (Pol PP), Police (Direskrim), and Semarang City Regional Revenue Agency (Bappenda), private parties (stakeholders), as well as community elements who can work together to formulate management strategies to solve problems parking in the city of Semarang.

\section{Review of Literature}

\subsection{Parking, On Street-Parking and Illegal Parking}

In Law No. 22 of 2009 concerning Road Traffic and Transportation, it is explained that Parking is a state of the vehicle stopping or not moving for a while and the driver is abandoned. According to Suwardjoko Warpani, not all vehicles move continuously, there are times when they stop for a while (lower the load) or stop for a long time, this is called parking (Warpani, 2002). Meanwhile, according to Tobing (2007: 1), parking is a condition where the vehicle does not move permanently. This definition distinguishes it from other conditions often encountered in traffic regulations, namely "stop" which is defined as a state of temporary stopping of a vehicle, such as stopping when dropping off or picking up passengers. If the vehicle stops, then the engine is turned off and the driver goes out or leaves the vehicle, it can no longer be said to be a stop but a parking.

On Street Parking is on-street parking. On street parking is a type of parking that is placed along the edge of the road with or without widening the road itself for parking facilities. This type of parking is very beneficial for visitors who want to park close to their destination.

In contrast to those that are legally managed by the authorities, where the revenue goes to the regional treasury, illegal parking is parking that occurs illegally or unofficially by claiming a parking space unilaterally. Besides, this parking is not registered and is not under the guidance of the district or city government and the money from parking does not go to the government as a form of local revenue (RAC Foundation, 2004; Setya, 2013; Harmoko, 2014). In the Big Indonesian Dictionary (2011) that the word 'wild' or 'illegal' 
means illegitimate according to law, in this case it violates the law, illegal goods, illegal, or there is no permission from the party concerned.

\subsection{Parking Management}

In developed countries parking management is very important for urban mobility, both in increasing accessibility and in overcoming urban congestion. In modern mobility management parking is the single greatest management tool (Knoflacher, 2006).

Public transport systems in major cities in developed countries have been provided with high-quality, well-integrated services, and large subsidies, therefore, enable them to offer regular passengers. As a result, these countries have focused their parking management on the development and expansion of park-and-ride facilities, namely parking facilities and supplemented by public transportation that connects the lane from the parking pocket to the destination. Like cities in Germany, the construction of park-and-ride facilities is seen as important to retain customers moving to the suburbs (Pucher, 2014).

Parking facilities are costly to construct, and parking conflicts are one of the most common problems facing designers, operators, planners and other officials. Such problems we often encounter either in terms of the supply of parking bags (too little space available, someone has to build more) or in terms of management (the available facilities are used inefficiently and must be better managed). In large cities in developed countries such as Canada's Victoria Institute's transport policy governing parking, management solutions tend to be better than expanding their availability because they support more strategic planning objectives, such as the following:

1. Reducing development costs and increasing affordability.

2. More compact and multi-modal community planning (Smart-Growth).

3. Promote the use of alternative modes and reduce the use of motorized vehicles (thereby reducing traffic congestion, accidents and pollution).

4. Improved quality of better service options for users, especially for non-drivers.

5. Increased design flexibility, as well as creating a more functional and attractive community.

6. Ability to accommodate (parking service users) and respond to new demands.

7. Reducing development that can block water absorption so that it is beneficial in protecting the environment and aesthetics.

Parking management refers to policies and programs that result in more efficient use of parking resources. Parking management includes several specific strategies. When parking management is implemented properly it can significantly reduce the number of parking spaces required in certain situations, providing a variety of economic, social and environmental benefits. When all impacts are considered, better management is often the best solution to parking problems. Siregar (2020) stated that Conflicts can have a negative impact on the parties directly involved or on the people around them if they are not resolved with proper conflict management.

In this study, we try to summarize the book Parking Management Best Practices published by Planners Press in 2006, which describes parking management strategies, how to evaluate strategies and build a well-integrated parking plan regarding general principles of parking management, and the benefits of management The following are matters related to Parking Management Best Practices:

\section{a. Parking Management Principles}

These ten general principles can help guide planning decisions to support parking management. 
1. Consumer choice. People must have proper parking and a purpose of travel.

2. Drivers must have information about their parking and travel options.

3. Parking facilities must serve a variety of users (parking service users)

4. More efficient use of parking lots (alternately)

5. Flexible

6. Prioritizing parking spaces with higher usage.

7. Direct payment system for using parking services.

8. Priority management.

9. The quality of parking facilities must be considered as important as quantity, including aesthetics, security, accessibility and user information.

10. Comprehensive analysis. All significant costs and benefits must be considered in parking planning.

\section{b. Benefits of Parking Management}

1. Savings in facility costs.

2. Improved service quality.

3. More flexible facility location and design.

4. Increase the revenue from parking revenue.

5. Reducing land consumption.

6. Supports mobility management.

7. Supports Smart Growth.

8. Increase the need for walking.

9. Supports systems that are oriented towards transit activities or transit use.

10. Reducing rainwater management costs, water pollution, and city heat effects.

11. Support equity objectives.

12. A more livable community.

\section{c. Parking Management Strategy}

This section describes specific parking management strategies. For more information see Litman (2006a) and related chapters on VTPI (2005).

\section{Shared Parking}

Parking together means a parking facility that serves users who want to reach their destination ("Parking Together," VTPI, 2005). This works best when destinations have different peak periods, or if they share customers so that motorists park at one facility and walk to multiple destinations. Parking facilities can be shared in a number of ways.

\section{Space is Divided not Reserved}

Drivers share the parking space, rather than being given the reserved space. For example, 100 employees can usually share 60-80 parking spaces, because at any given time some are on leave, traveling in alternative modes, in the field, or working other shifts. Hotels, apartments, condos and dormitories can share parking space among multiple units, as the number of vehicles per unit varies from time to time.

\section{Share Parking Between Destinations}

Parking can be shared among various destinations. For example, an office building may share a parking space with a restaurant or theater, since peak demand for offices occurs during weekdays, and on weekend nights for restaurants and theaters. Sharing 
systems involve using land in one location, such as a mall or campus, or by making sharing arrangements between sites that are located close together.

\section{Public Parking Facilities}

Public parking includes on-street, off-town, and commercial (for profit) facilities generally serving many purposes. Switching from free to paid public parking, allowing for more efficient sharing.

\section{Replacement Cost}

"Replacement cost" means that the developer helps fund public parking facilities rather than providing a private facility that serves a single purpose. These tend to be more cost effective and efficient.

\section{Special Parking Ratings}

Businesses in an area can be assessed with a special assessment or tax to fund parking facilities in their area, as an alternative to any business that provides its own facilities. This is often implemented through business upgrades in the city center.

\section{d. Parking Paradigm Shift}

Parking management represents a paradigm shift, namely a fundamental change in how a problem is perceived and solutions are evaluated. The current paradigm assumes that the more parking is available, the better. This in itself creates the condition that the availability of abundant parking increases vehicle use and urban expansion, causing the demand for parking and parking supply to increase. It reflects planning in which past trends are evaluated to predict future demand, which policymakers then try to fulfill.

Table 1. Parking Paradigm

\begin{tabular}{|c|c|}
\hline Old Paradigm & New Paradigm \\
\hline $\begin{array}{c}\text { "Parking problem" means inadequate } \\
\text { parking supply. }\end{array}$ & $\begin{array}{c}\text { "Parking problems" can mean inadequate } \\
\text { land availability, inefficient management, } \\
\text { inadequate information, and other } \\
\text { problems related to parking facilities and } \\
\text { activities. }\end{array}$ \\
\hline $\begin{array}{c}\text { More parking space is better } \\
\text { parking should generally be provided free } \\
\text { of charge. Where possible, parking } \\
\text { facilities should be funded indirectly, } \\
\text { through building leases or taxes. }\end{array}$ & $\begin{array}{c}\text { Too much capacity is as dangerous as too } \\
\text { little. }\end{array}$ \\
\hline $\begin{array}{c}\text { Parking must be available on a first come } \\
\text { first served basis. }\end{array}$ & $\begin{array}{c}\text { Parking should be arranged to support } \\
\text { priority parking only to support efficiency. }\end{array}$ \\
\hline $\begin{array}{c}\text { Parking requirements must be applied } \\
\text { consistently, without exception or } \\
\text { variation. }\end{array}$ & $\begin{array}{c}\text { Parking requirements must be applied to } \\
\text { each particular situation, and must be } \\
\text { applied flexibly. }\end{array}$ \\
\hline $\begin{array}{c}\text { Traditional solutions should take } \\
\text { precedence. This new approach must be } \\
\text { prevented because it is not proven and is } \\
\text { not widely accepted. }\end{array}$ & $\begin{array}{c}\text { Innovation must be encouraged, because } \\
\text { even unsuccessful experiments often } \\
\text { provide useful information. }\end{array}$ \\
\hline
\end{tabular}




\begin{tabular}{|c|c|}
\hline $\begin{array}{c}\text { Parking management should only be } \\
\text { implemented as a last resort, as it will be } \\
\text { too expensive to increase supply. }\end{array}$ & $\begin{array}{c}\text { Parking management programs should be } \\
\text { widely implemented to prevent parking } \\
\text { problems. }\end{array}$ \\
\hline $\begin{array}{c}\text { One of the "transportation" is driving. } \\
\text { Spread of purpose (expansion of the city) } \\
\text { can be accepted or even expected. }\end{array}$ & $\begin{array}{c}\text { Car traffic is a part of the transportation } \\
\text { system. A car-dependent and scattered land } \\
\text { use pattern may not be desirable. }\end{array}$ \\
\hline
\end{tabular}

\subsection{Collaborative Governance}

In recent decades, new forms of governance have emerged to replace managerial modes of policy making and implementation. Collaborative governance, basically bringing together public and private stakeholders in a collective forum with public bodies to engage in consensus-oriented decision making.

In particular, collaborative governance places multisectoral participants on the emphasis between voluntary collaboration and horizontal relationships, because public needs cannot be met by public institutions as a whole, thus requiring interaction between various institutions or organizations involved and involved in public activities (Agranof \& McGuire; Joo Chang, 2009). In addition, Alter and Hage (1993) explain that collaborative efforts arise as a result of a flexible approach to achieving goals by achieving more creative goals in a shorter time when compared to organizations working alone.

A number of case studies show that collaboration is more likely to occur when there are concrete goals and benefits (small wins) from the collaboration (Chrislip and Larson 1994; Roussos and Fawcett 2000; Warner 2006; Weech-Maldonado and Merrill 2000). While these intermediate outcomes may represent tangible outcomes, we present them here as important process outcomes essential to building momentum that can lead to successful collaboration. These small wins can feed into the collaborative process, fostering a sound cycle of building trust and commitment (Rogers et al. 1993; Vangen and Huxham 2003b). Collaborative governance is a forum to achieve goals. According to Donahue and Zeckhauser (2011: 4), collaborative governance is a condition in which the government fulfills public goals through collaboration between organizations or individuals. The same thing is also explained by Holzer et al., (2012: 349) which states that collaborative governance is a condition in which the public sector (government) and the private sector strive to achieve a common goal for society. In the collaborative governance process it can be seen by the existence of activities cooperation between institutions due to the limited ability of each institution or institution to carry out its own programs and activities. Limitations from the aspect of need can be in the form of budget funds or human resources (HR) from one of the institutions / institutions involved in the collaboration. 


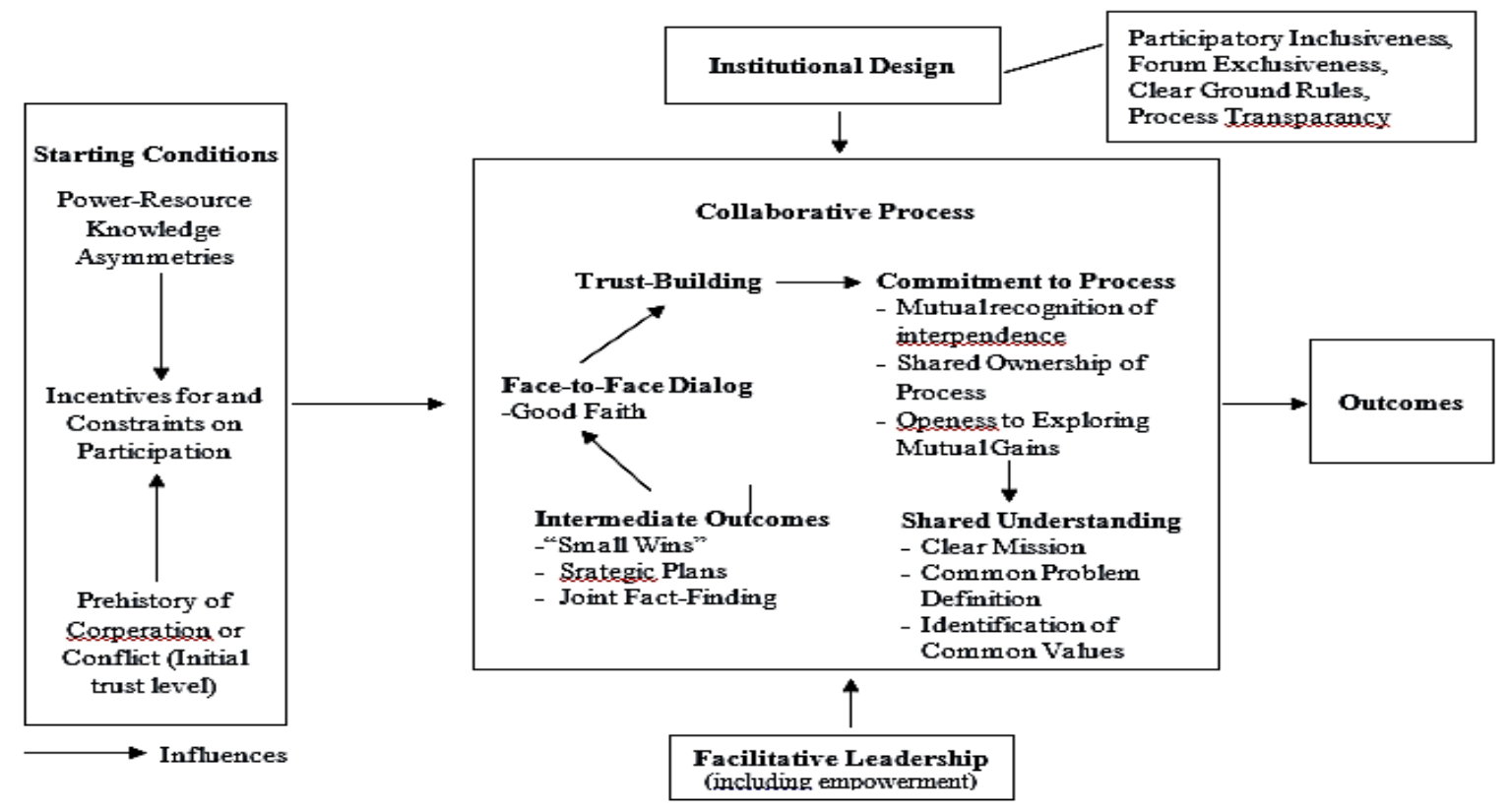

Figure 1. Anshall and Gash's Collaborative Governance Model

The process of collaborative governance is carried out in several stages. The stages of the collaboration model are important to consider as a strategy in the management aspect of a public affair. In Ansell and Grash's theory (2007: 15) the collaborative stages are as follows:

1. Starting Condition

2. Facilitative Leadership

3. Institutional Design

4. Collaborative Process The collaborative process model depends on how the participants can achieve a good cycle between communication, trust, commitment, understanding, and results (Huxham 2003; Imperial 2005). The stages of forming a collaborative are as follows:

a. Face to face dialogue.

b. Building Trust (Trust Building)

c. Commitment to the Process

d. Shared Understanding

e. Intermediate Outcomes

The concept of governance or one of the ways to run government is collaborative governance or what is known as collaborative governance. According to Ansell and Grash's opinion, "Collaborative governance is therefore a type of governance in which public and private actors work collectively in a distinctive way, using particular processes, to establish laws and rules for the provision of public goods" (Ansell and Gash, 2007: 545).

In the context of roadside management, this collaboration parameter is important to be used as a reference in implementing collaboration. With the existence of collaborative activities between actors, there are efforts to improve the quality of professional performance due to developments in the aspects of facilities and infrastructure as well as human resources of these institutions.

Collaborative Governance is a control model in which one or more public institutions are involved in formal, consensus-oriented, deliberative collective decision-making processes that aim to make or implement public policies, manage public programs and assets. 


\section{Research Methods}

This study uses descriptive qualitative methods with the aim of understanding social phenomena or symptoms with a focus on a complete picture of the phenomenon being studied. The study was intended to determine the process of collaborative management carried out by stakeholders in parking management in the city of Semarang. The location of the research taken is the city of Semarang by determining the informants using purposive sampling technique, which has determined who the parties involved and authorized to provide information in this study.

In this study, Kota Lama Semarang was chosen as the research location, where this location is a parking pocket point that has the potential to be disorderly and there are indications of illegal parking practices in the city of Semarang. Data collection is carried out through primary and secondary data sources. Primary data were obtained from interviews with key informants. In this case the Department of Transportation is the main informant as the sector leading in the management of roadside parking in the city of Semarang. Besides other infoerman-informants to support the validity of the data. For primary data, direct observation has also been carried out. Secondary data is data obtained from documentation, literature from journals, books, and mass media as well as documents at the Semarang City Transportation Agency.

\section{Results and Discussion}

The strategy in managing public roadside parking that can be carried out by the Semarang City Government as one of the pillars of public service providers and is a major element in implementing public policy is expected to be able to realize good governance, especially in managing parking so that it can improve order, potential income retribution, as well as the welfare of the people of Semarang City. Collaboration in parking management must also be done in an effort to maintain relationships between organizations or institutions.

However, in implementing the Semarang City Government, there are still many obstacles. In general, roadside parking management in Semarang City is still far from good. The results of the study found that there are still many illegal parking practices on the side of the road and a lack of public awareness as parking service users who park their vehicles not in the parking spaces that have been provided. There are still many people who feel reluctant because the location of the parking point to the destination is considered quite far.

In the discussion report of Commission B DPRD Semarang City, it is stated that realization income mlow compared to the calculated target, from the projection of parking intensity at each point with the percentage obtained from users of parking services. This is sufficient to prove that the management of public roadside parking in Semarang City is still poor, even though as the capital city of Central Java, Semarang City has quite a high parking potential. Even in 2019, assuming the projected subscription parking system (eparking), the target could reach Rp. 115 Billion (One Hundred and Fifteen Billion Rupiah), but the realization of revenue in that year was only around $\mathrm{Rp} 2.9$ billion, which means that they only received $2.6 \%$ of the revenue target and the target they set was only Rp 3.3 billion in 2020 Due to the small amount of revenue realization of this parking fee, making this parking management problem received the spotlight from the Commission $\mathrm{C}$ of the Semarang City DPRD and also the Supreme Audit Agency (BPK RI). This has prompted several DPRD members to form a working committee (Panja) to boost revenue from the 
public roadside parking sector. The Department of Transportation as the implementer of the policy must find other methods, after the subscription parking policy cannot be implemented.

From the existing phenomena, the researchers assessed that there were weaknesses in carrying out the policy. The Semarang City Government has not yet carried out government collaboration involving the important elements in charge of public roadside parking management. Semarang City Government should be able to involve private, nonstate stakeholders and the general public. According to Ansell ang Gash in the e Journal of Public Administration Research and Theory (2007) explains that variables are collaborative processes treated as the core of this model, with initial conditions, institutional designs, and leadership variables represented as important contributions or contexts for collaborative as the following process:

\section{a. Starting Condition}

In the initial conditions, the Semarang City Government invited other institutions to coordinate in order to formulate policies on parking management. There are elements of the police, Bappenda, private parties (stakeholders), and also the Civil Service Police Unit, there are elements of the community who are involved. Approach community groups who are able to participate in managing roadside parking.

\section{b. Facilitative Leadership}

The Semarang City Government, in this case the Semarang City Transportation Agency, has not been able to create a collaborative process between institutions that have authority, it requires credible technical skills and the ability to build mutual trust between the policy actors involved.

\section{c. Institutional Design}

Ansell and Gash (2007: 13) describe that institutional design refers to the basic protocol and basic rules for collaboration. The most critically emphasized is procedural legitimacy in the collaboration process. In the collaborative process, it must be emphasized that the government must be open and inclusive.

1. Face to Face Dialogue

In carrying out the management of public roadside estimates, the Semarang City Government conducts face-to-face dialogue with various parties, both private parties, including involving community groups (non-state) and the general public.

2. Trust Building

The formation of trust between parties cannot be separated from the communication carried out by the Semarang City Government and the parties involved. In building this trust, it is necessary to have transparency from all parties so that the same understanding will be realized.

3. Commitment to the Process

Commitment is an important component in the collaboration process. Commitment in implementing roadside parking management is the responsibility of all parties involved, a strong commitment from each stakeholder is needed to prevent risks. The Semarang City Government as the main actor in parking management needs to accommodate commitments by making MoUs and legitimacy based on established regulations.

4. Share Understanding

In implementing collaborative governance between the Department of Transportation, Pol PP, Polres, Bappenda for the City of Semarang as well as the private sector and the 
community, it is necessary to take strategic steps to determine the phases in the roadside parking management strategy. To provide a perspective regarding the role of each party in the success of parking governance. The consensus reached concerns the following stages:

a) Parking Management.

b) Determination of parking points and / or bags

c) Policies and Regulations

d) Socialization

e) Punishment

The parking management strategy that is important and urgent in collaboration that stakeholders can undertake, as well as the implementation of each of these policies is described as follows:

1) Formulation and stipulation of special regulations on parking management;

The regulation that guides the implementation of parking at this time is Regional Regulation No. 1 of 2004 which was updated with Regional Regulation No. 6 of 2018. So there needs to be a special Regional Regulation that regulates public parking management.

2) Socialization, advocacy, persuasive approaches and public campaigns on parking;

(i). The parking arrangement socialization can be conveyed to all related elements and the general public. So that understand the provisions that are applied in order to provide good service to the public.

(ii). Advocacy is considered very important so that all elements can understand how the parking management rules are applied, things that cause violations will be followed up as punishment.

(iii). The social aspects that emerge in the implementation of this parking management policy can be overcome by a persuasive approach, a win-win solution can be offered so as not to harm various parties and not to have a negative impact on the environment.

3) Strengthening and enforcing the law in sustainable parking management;

Strengthening and enforcing the law need to be affirmed by the regional government, after going through a persuasive approach there is also a need for assertiveness in implementing legal consequences for the parties who commit violations. Because the government is the main tool in implementing governance.

4) Development of parking space accessibility / infrastructure (parking space / building); From the parking problems that arise, one of which is the lack of proper parking space (parking space), parking infrastructure / buildings, and public transportation facilities from the parking location to the destination location. In this case, it will provide easy accessibility for consumers (parking service users).

5) Development and application of e-parking system technology;

The forecasting sector is often in the spotlight because of the lack of income from parking fees. Some people and even legislative elements say that the public parking sector is actually the prima donna for increasing PAD, but the leakage from the revenue from this levy causes the PAD target to be often not achieved. (Republika.co.id - 29 June 2018). For this reason, the importance of the application of e-parking application system technology for objective management of the parking sector revenue. In addition, the application of e-parking system technology will minimize illegal fees.

6) The implementation of collaborative governance and institutional strengthening;

From the perspective of collaborative governance, several agencies and institutions have the authority in parking management, the synergy of each element needs to be integrated. Parking management authority cannot be separated from the involvement of 
the private sector, parking management will be more optimal if it involves nongovernment (private) elements so that the government does not become the sole actor. Local government can cooperate with the community and of course with the provisions that have been determined.

7) Developing the commitment of administrators of authority to management of estimates; The importance of commitment of each agency and agency authorized in the management of estimates so that the implementation of parking management shows optimal achievement of goals. If there is no good communication and cooperation to carry out its duties and functions, it will be difficult to realize the goals and the problem of estimating will never be resolved.

8) Increasing human resources (HR) in managing parking;

Human resources (HR) is a very important aspect in determining good parking management. Semarang City Government needs to prepare professional resources. In this case, the parking attendant is the main element dealing directly with the community, so that in the application of technology, the parking attendant is able to use and operate the technology appropriately.

\section{Conclusion}

In the process of collaboration between stakeholders in the management of roadside parking, it is considered not optimal, where the collaborating parties are not yet on target so that subjectivity and politicization in parking management appears. In the collaboration stage, initial dialogue preparations involving several stakeholders are initiated and supported by informal communication within the frame of discussing the problem. Then trust is also formed between each party in cooperation. Continued commitment to build by making the MoU that was set. The last collaborative process is to build an attitude of mutual understanding which results in the output of preparation for implementing a parking management strategy. The output formed from the collaborative building process is a parking management strategy / parking management.

From these conclusions, the suggested efforts related to the research carried out are:

1. It is necessary to create a joint agenda between stakeholders and the Semarang City Government as stakeholders and policy makers to build the principle of mutual trust (trust building) considering that the Semarang City Government is no longer the sole actor in parking management;

2. There needs to be a comprehensive regulation or a special parking policy such as the Perda on Parking so that it can become a foothold in implementing control;

3. The Semarang City Government provides an open opportunity for private parties and the general public to manage parking management so as to avoid politicization and monopoly in parking management as well as assertiveness in determining the parties to collaborate in the implementation of parking management and on target;

4. Prepare facilities and infrastructure with the support of the parties involved in the collaboration.

5. There is a joint commitment in implementing agreements that have been made and are consistent;

6. There needs to be routine socialization related to the implementation of parking-related regulations to the public. 


\section{References}

Budi Winarno. (2012). Kebijakan Publik Teori Proses dan Studi Kasus, Center for Academic Publishing Service (CAPS), Sleman

Chris Ansell and Alison Gass. (2007). Collaborative Governance in Theory and Practice, Journal of Public Administration Research and Theory of Oxford University Press.

Dimas Luqito Chusuma Arrozaaq, COLLABORATIVE GOVERNANCE (Studi Tentang Kolaborasi Antar Stakeholders Dalam Pengembangan Kawasan Minapolitan di Kabupaten Sidoarjo), Mahasiswa program studi Ilmu Administrasi Negara, FISIP, Universitas Airlangga

Djunaedi Achmad. (2020). Proses Perencanaan Strategis Kota / Daerah. Universitas Gajah Mada.

Hardiansyah Hutabarat dan R Slamet Santoso, Evaluasi Kebijakan Retribusi Parkir di Tepi Jalan Umum Kota Semarang, Departemen Administrasi Publik Fakultas Ilmu Sosial dan Ilmu Politik Universitas diponegoro

https://republika.co.id/berita/nasional/daerah/18/06/29/pb3d38284-parkir-di-kotasemarang-disebut-masih-jadi-pr (accessed on Sunday, 4 October 2020, 13.25)

https://sigijateng.id/2020/dprd-curiga-ada-kebocoran-pendapatan-parkir-kota-semarangjauh-di-bawah-target/ (accessed on Friday, 9 October 2020, 13.25)

https://www.semarangpos.com/keluhkan-tarif-parkir-di-jl-pandanaran-warganet-laporwali-kota-semarang-1039367 (accessed on Friday, 9 October 2020, 13.25)

https://www.ayosemarang.com/read/2020/02/18/52415/pantau-kota-lama-dewan-sorotipersoalan-parkir (accessed on Friday, 9 October 2020, 13.25)

https://halosemarang.id/rendahnya-pencapaian-pendapatan-parkir-tepi-jalan-umum-dikota-semarang-jadi-sorotan-dprd (accessed on Friday, 31 October 2020, 19.00)

https://halosemarang.id/parkir-liar-masih-menjadi-persoalan-penataan-kota-lama-semarang (accessed on Sunday, 18 April 2021)

John M. Bryson, Barbara C. Crosby and Laura Bloomberg. (2014). Public Value Governance: Moving beyond Traditional Public Administration and the New Public Management, Journal of Public Administration Review , JULY/AUGUST 2014, Vol. 74, No. 4, pp. 445-456

John W. Cresswell. (2017). Research Design Pendekatan Kualitatif, Kuantitatif, dan Mixed Edisi Ketiga, Pustaka Pelajar. Yogyakarta

Kementerian PPN / Bappenas. (2015). Manajemen Parkir di Perkotaan, Jakarta.

Kurniadi. (2020). Collaborative Governance dalam Penyediaan Insfrastruktur, DEEPUBLISH CV. BUDI UTAMA. Yogyakarta. Kurniadi, 2020, Collaborative Governance dalam Penyediaan Insfrastruktur, DEEPUBLISH CV. BUDI UTAMA. Yogyakarta.

La Ode Syaiful Islamy H. (2018). Collaborative Governance Konsep dan Aplikasi. DEEPUBLISH CV. BUDI UTAMA. Yogyakarta.

M.Eng. Truong Thi My Thanh. (2018). Parking Management Strategies for Asian Developing Countries Approved Dissertation, Institute of Transport Planning and Traffic Engineering, V 39 ISSN 1613-8317 Darmstadt.

Muh. Arief Effendi. (2018). The Power of Good Governance Teori dan Implementasi Edisi 2, Salemba Empat. Jakarta

Nicola Ulibarri. (2019). Collaborative governance: a tool to manage scientific, administrative, and strategic uncertainties in environmental management, Journal of Ecology and Society, Vol. 24, No. 2. 
Sarah Brooke, Stephen Ison and Mohammed Quddus. (2017). "On - Street parking search", Journal of Transport and Land Use, 2017, Vol. 10, No. 1, pp. 13-26

Siregar, F. H. (2020). Relationship Emotional Intelligence with Conflict Management in Employees of PT. Aspacindo Kedaton Motor. Budapest International Research and Critics Institute-Journal (BIRCI-Journal) Vol 3, No 2, Page: 1251-1261

Syaffa Rahmah, Evaluasi Terhadap Pengelolaan Parkir Tepi Jalan Umum Di Kawasan Simpang Lima Kota Semarang.

William N. Dunn. (1998). Pengantar Analisis Kebijakan Publik, Gajahmada University Press, Yogyakarta 